\title{
Atlantis
}

Critical Studies in Gender, Culture \& Social Justice

Études critiques sur le genre, la culture, et la justice

\section{Feminist Praxis Revisited: Critical Reflections on University-Community Engagement}

\section{Jennifer Musial}

Volume 41, Number 1, 2020

URI: https://id.erudit.org/iderudit/1074023ar

DOI: https://doi.org/10.7202/1074023ar

See table of contents

Publisher(s)

Mount Saint Vincent University

ISSN

1715-0698 (digital)

Explore this journal

Cite this review

Musial, J. (2020). Review of [Feminist Praxis Revisited: Critical Reflections on

University-Community Engagement]. Atlantis, 41(1), 124-126.

https://doi.org/10.7202/1074023ar 


\section{Feminist Praxis Revisited: Critical Reflections on University-Community Engagement}

Jennifer Musial is an Assistant Professor of Women's and Gender Studies at New Jersey City University in Jersey City, NJ. She earned her PhD in Women's Studies from York University (Toronto, ON). She publishes in three fields; 1) reproductive justice, racialization, and gender-based violence; 2) critical yoga studies; and 3) Women's and Gender Studies field formation. Her major project-in-progress, Pregnant Pause: Reproduction, Death, and Media Culture, looks at racialized grievability in media cases of fatal violence against pregnant women. Previous work has been published in Sexualities, Feminist Formations, Social Identities, Atlantis, Feminist Teacher, and the Journal of Criminal Justice Education. She has forthcoming chapters in the edited collections Rethinking Women's and Gender Studies Volume II and Carcerality Locally and Globally: Feminist Critiques of States of Violence. She is the managing editor for Race and Yoga, a peer-reviewed journal that looks at the intersections of yoga, racialization, colonialism, capitalism, gender, sexuality, and disability studies.

Book under review: Dean, Amber, Johnson, Jennifer L., and Susanne Luhmann, eds. 2019. Feminist Praxis Revisited: Critical Reflections on University-Community Engagement. Waterloo: Wilfred Laurier Press.
M ore than ever, Canadian universities are giving civic engagement (CE) (i.e. service learning, internships, community-based research, field placements, co-op, practicum, etc.) a central role in their strategic plans. Given that one of the pillars of Women's and Gender Studies (WGS) has been "refusing to accept the sterile divisions between academy and community" (National Women's Studies Association 2002), it would seem that WGS is poised to be a leader in this higher education orientation. Feminist Praxis Revisited questions the supposed alignment between our field and civic engagement as an emerging priority within higher education. While activism, community engagement, and praxis are fundamental to WGS, what is the effect of these initiatives on the field, students, and communities? Are we achieving our goals of exposing students to feminist activism "on the ground" by allowing them to apply in-class learning? Do students leave these classes with an enhanced civic identity and commitment to dive into the "real" work of feminism? Feminist Praxis Revisited asks these and even more pointed, and difficult, questions. For instance, despite our best intentions, is WGS contributing to neoliberalism, white centricity, and colonial impulses, as well as class or regional chauvinism, through CE? Does WGS reinforce a town/gown divide by assuming feminist praxis must happen "elsewhere"?

Feminist Praxis Revisited contains a series of chapters edited by Amber Dean, Jennifer L. Johnson, and Susanne Luhmann, each of whom has an established publication record in feminist pedagogy and civic engagement. The book features substantive chapters by Canadian scholars who teach feminist CE courses within their home disciplines, and the editors have selected authors that are located at Canadian universities ranging from small teaching-focused institutions to larger research-focused schools. The book is organized into two sections: Feminist Praxis/For Credit/Under Neoliberalism and Critical Approaches to Praxis/In 
and Out of the Classroom. In each, authors describe their forays into feminist CE against the backdrop of federal and provincial cuts to education. Usefully, the book contains some chapters by activist-academics who speak to how economic austerity harms social services, non-profits, and academia alike.

A critique of neoliberalism underlies the arguments of the book. In their chapters, Joanne Muzak, Lise Gottell, and Judith Taylor remind that governments have cut funding for both higher education and social services; feminist organizations are particularly vulnerable because they did not recover when the Harper government slashed support for the Status of Women Canada. CE mandates fill this gap in two ways: first, governments can frame $\mathrm{CE}$ as job training thereby concretizing the dream of a university-to-workplace pipeline; second, organizations may look to unpaid students to do the work of formerly paid staff. The irony is that once a student graduates, the job they supposedly "trained" for at an organization is not there. Muzak effectively argues that WGS professors are mistaken when they assume that students will learn or observe feminist activism through a community project; she reminds that the Harper government (as well as subsequent provincial governments) penalized organizations for their social justice motivation. In order to survive, many organizations drifted towards apolitical service provision. Taylor illustrates why this creates the ground for a failed experience: students enter these sites in a heightened critique mode that they turn on community workers for not doing feminism "right." Taylor argues that students may not have the experience or humility to appreciate the messiness of feminist work. Catherine Orr's conclusion to the book pulls these lines of argument together by advocating uneasiness - the not-quite-right feeling - that is productive for learning as well as dismantling privilege.

In addition to critiquing neoliberalism, Feminist Praxis Revisited re-thinks the assumption that feminist CE best happens outside university walls. This intervention unpacks where learning "should" to occur. Other CE scholars dismantle the deficit model that positions communities — often racialized, Indigenous, and/or poor-as in need of saving or fixing (Butin 2008;
Mitchell 2008). In this collection, chapters by Amber Dean, Sarita Srivastava, Ilya Parkins, Judith Taylor, and Jennifer L. Johnson offer a similar critique of academic saviorism. I was particularly struck by Dean and Rachel Alpha Johnston Hurst's assertion that an us/ them divide not only leaves the university unchecked as a site of harm but assumes that students do not have a role to play in addressing problems at the university itself. What if the best site for feminist praxis is not "out there" but right here? This question shifts what $\mathrm{CE}$ is supposed to be, and Jennifer L. Johnson's rumination on the territorialization of feminist praxis/CE at the end of the book is a solid dénouement for this inquiry.

One of my frustrations with CE literature is how often it centralizes a privileged academic experience: the white middle class student who lives away from family on or near campus. As someone who teaches at a commuter school with a student population that is mostly racialized, working poor, from local urban neighbourhoods, and first generation to college, I appreciate that several chapters in Feminist Praxis Revisited acknowledge that students may be living in their own communities while attending university. I do wish, however, that at least one chapter focused on feminist praxis in this context because it is sorely lacking in CE research. Despite this absence, Srivastava and Johnson promote feminist praxis where students live. These authors remind that students have the potential to intervene, build, or shape communities where they already are, which may be more empowering and transformative for students (and communities) than sending students into an environment where they have no ties. In addition to engagement-in-place feminist praxis, deep learning can happen through self-reflexivity about social location and ancestral history. As explained in their respective chapters, Dean, Parkins, and Margot Francis ask students to examine how they are implicated in white settler colonialism. Feminist professors can activate relational responsibility by requiring settler-students to reckon with their lack of innocence in the colonial project of nation-building. This kind of praxis can instill life-long reflexivity that is lacking in the "one and done" CE model that assumes student transformation will occur through one CE class. 
Notably missing from Feminist Praxis Revisited is engagement with Tania D. Mitchell's work on critical service-learning, a sub-field of CE that advocates redistributing power, social change, and developing authentic relationships through CE courses (Mitchell $2008,53)$. Conversation with her work would heighten the book's usefulness for CE scholars. Feminist Praxis Revisited is best read alongside scholarly appraisals of the activist intention of WGS (Orr 2012). The chapters written by activist-academics who have one foot in each world are especially valuable to understand the misalignment between WGS and shifting terrain of grassroots work. Readers looking for a "how to" manual are better served by reading Karen Dugger's Handbook on Service Learning in Women's Studies and the Disciplines (2008). However, the descriptions in Feminist Praxis Revisited of what has been tried, what has worked, and what has not not worked in the classroom are helpful to those teaching feminist CE courses. In addition to CE scholars and WGS professors or feminist teachers, those in critical university studies will appreciate the book's critique of how neoliberalism shifts higher education.

\section{References}

Butin, Dan W. 2008. "The Limits of Service-Learning in Higher Education." The Review of Higher Education 29, no.4: 473-498.

Dugger, Karen, ed. 2008. Handbook on Service Learning in Women's Studies and the Disciplines. Towson, MD: Institute for Teaching and Research on Women.

Mitchell, Tania D. 2008. “Traditional vs. Critical Service-Learning: Engaging the Literature to Differentiate Two Models." Michigan Journal of Community Service Learning 14: 50-65.

National Women's Studies Association. 2002. "Preamble to the Constitution of the National Women's Studies Association." NWSA Journal 14, no. 1: xix-xx.

Orr, Catherine M. 2012. “Activism.” In Rethinking Women's and Gender Studies, edited by Catherine M. Orr, Ann Braithwaite, and Diane Lichtenstein, 85101. New York: Routledge. 